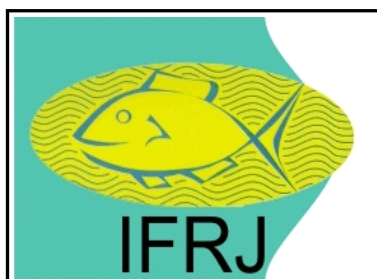

Available online at: http://ejournal-balitbang.kkp.go.id/index.php/ifrj

e-mail:ifrj.puslitbangkan@gmail.com

INDONESIANFISHERIES RESEARCHJOURNAL

Volume 22 Nomor 2 December 2016

p-ISSN: 0853-8980

e-ISSN: 2502-6569

Accreditation Number: 704/AU3/P2MI-LIPI/10/2015

\title{
CATCH COMPOSITION AND SOME BIOLOGICAL ASPECTS OF SHARKS IN WESTERN SUMATERA WATERS OF INDONESIA
}

\author{
Dharmadi $^{\star 1}$, Mahiswara² and Kamaluddin Kasim ${ }^{1}$ \\ ${ }^{1}$ Research Center for Fisheries Research and Development, Jl. Pasir Putih II Ancol Timur, Jakarta. Indonesian \\ ${ }^{2}$ Research Institute for Marine Fisheries, Jl. Muara Baru Ujung, Komp Pelabuhan Perikanan Nizam Zachman, Penjaringan, \\ Jakarta Utara, Jakarta - 14440. Indonesian \\ Received; Sept 22-2015 Received in revised from Dec 20-2016; Accepted Dec 21-2016
}

\begin{abstract}
ABTRACT
This study was conducted in western Sumatera and since October 2013 to June 2014. The sampling locations in Banda Aceh and Sibolga-North Sumatera which were the largest base of fisheries in western Sumatera region. Shark landing recorded by enumerators was used as sampling data daily. This research aim to describ sex ratio, size composition, catch composition of sharks, and length at first maturity. In Banda Aceh, the sharks as target fish collected by sorting the bycatch from tuna longlines and tuna handlines. In Sibolga, sharks is bycatch from fish net, bottom gillnet and purse seine. Overall, there were 20 species of shark caught in west Indian Ocean and landed at those fish landing sites, dominated by Spot tail shark (23\%) and Silky shark (13\%), whereas Hammerhead shark contributed about $10 \%$ and Oceanic whitetip shark was only less than $1 \%$. Almost of Spot tail shark, Silky shark, and Scalloped hammerhead that caught in that area were immature, while for the almost part of Tiger shark and Pelagic thresher were matured. The sex ratios for Spot tail shark, Silky shark, Tiger shark, Pelagic thresher, and Scalloped hammerhead caught and landed at Lampulo and Sibolga fish landing sites were not balance. The length at first maturity for Spot tail shark was $L m=87,1$ $\mathrm{cm}$ and $\mathrm{Lm}=213,2 \mathrm{~cm}$ total length for Tiger shark.
\end{abstract}

Keywords : Sharks; biology; fisheries; Western Sumatera

\section{INTRODUCTION}

Indonesia is the largest country in Southeast Asia, where shark and ray commodities have an important role. Especially, for shark fin trade. FAO data indicate that Indonesia is the largest shark producer in the world (Lack \& Sant, 2009), contributing around 12.3\% of total world production. However, shark production in Indonesia only contributes about $2 \%$ of the total marine fishery production. The Indonesian production of shark has shown a significant decrease in last two decades. It was recorded at 46.125 tonnes in 1991 and 42.036 tonnes (2012), but shark production increased to be 52.268 tonnes in 2013 (DGCF, 2014) and then decreased to be 49.020 tonnes (DGCF, 2015). Eventually, intensive shark fishing is likely to lead to depletion of Indonesia's shark populations, a pattern that is becoming apparent with the decreasing abundance and size of the sharks in the landings (Fahmi \& Dharmadi, 2013). Despite many years of international concern about the depletion of shark populations globally (including in Indonesia), with growing evidence that several species are endangered, populations continue to decline, which is due largely to ineffective fisheries management, lack of enforcement and/or poor implementation of existing regulations (Bonfil, 2002; Lack \& Sant, 2006; Fahmi \& Dharmadi, 2013). Shark fishing activities in Indonesia were mostly occurred as a bycatch (72\%) and only $28 \%$ were done as a targeted fishery (Zainuddin, 2011). In Indonesia, the most potential of shark fisheries region is Indian Ocean.

The shark fisheries region in western Sumatera contributed about $12.3 \%$ for national shark production (DGCF, 2013). Large contribution of captured shark was mostly from Banda Aceh and Sibolga, North Sumatera. Sharks landed in Lampulo-Banda Aceh are the catch of shark longline and as by catch from tuna long line and tuna hand line. Whilst in Sibolga, sharks as by catch were obtained by fish net, bottom gillnet and purse seine. There is a litle information about biology and shark fisheries that landed at West Sumatera. The main aim of this paper is to provide 
on species, size compositions, length frequency, sex ratio, and length at first maturity for both of Spot tail shark and Tiger shark from West Sumatera waters.

\section{MATERIALS AND METHODS}

This study were conducted since October 2013 to June 2014 at two fish landing sites, there were LampuloBanda Aceh and Sibolga-North Sumatera. The map of study areas has been shown in Figure 1. The shark landing recorded by enumerators was used sampling data daily. To avoid identification errors of this study, the enumerators also attached shark species photos which they are measured for cross checked in daily data collection form. The number of individuals of each species landed, their sex and their total length (TL) were recorded. In the case of males, the outer length of the clasper (LC), taken from lateral junction with pelvic-fin inner margin and apex of clasper, and its level of calcification, i.e. non-calcified, partially calcified or fully calcified, were recorded (where possible). The Length at first maturity $(\mathrm{Lm})$ of males was calculated by Carcharhinus sorrah and Galeocerdo cuvier, the only species with adequate number of males with claspers measured. Individuals with either non-calcified or partially calcified claspers were considered immature (juvenileyoung), while those with fully calcified claspers were considered mature (adult). (Fig. 2).
Estimation of the proportion of clasper mature were estimated using the following formula:

where:

$$
P_{m i}=\sum \frac{j m}{j m+j i} \times 100 \%
$$

$P_{\mathrm{mi}}=$ Proportion of mature fish at each length group; $\mathrm{J}_{\mathrm{m}}=$ Numbers of mature fish at each length group;

$J_{i}^{m}=$ Numbers of immature fish at each length group

Proportion of clasper mature at each length group then plotted as $\mathrm{Y}$-axis while length groups as $\mathrm{X}$-axis using S-shape curve. Generalized Linear Model (GLM) was used to estimate length at $50 \%$ maturity. Slope value $(b)$ from the model was recognize as the Length at first maturity $(\mathrm{Lm}), \mathrm{R}$ statistical tool was using analysis (King, 2007).

\section{RESULTS AND DISCUSSION \\ Results}

\section{Species Composition}

Total of 2,986 individual sharks, comprising 20 species and belonging to 10 families, were recorded at two main landing sites, Banda Aceh and Sibolgawestern Sumatera October 2013 to June 2014 (Table 1).

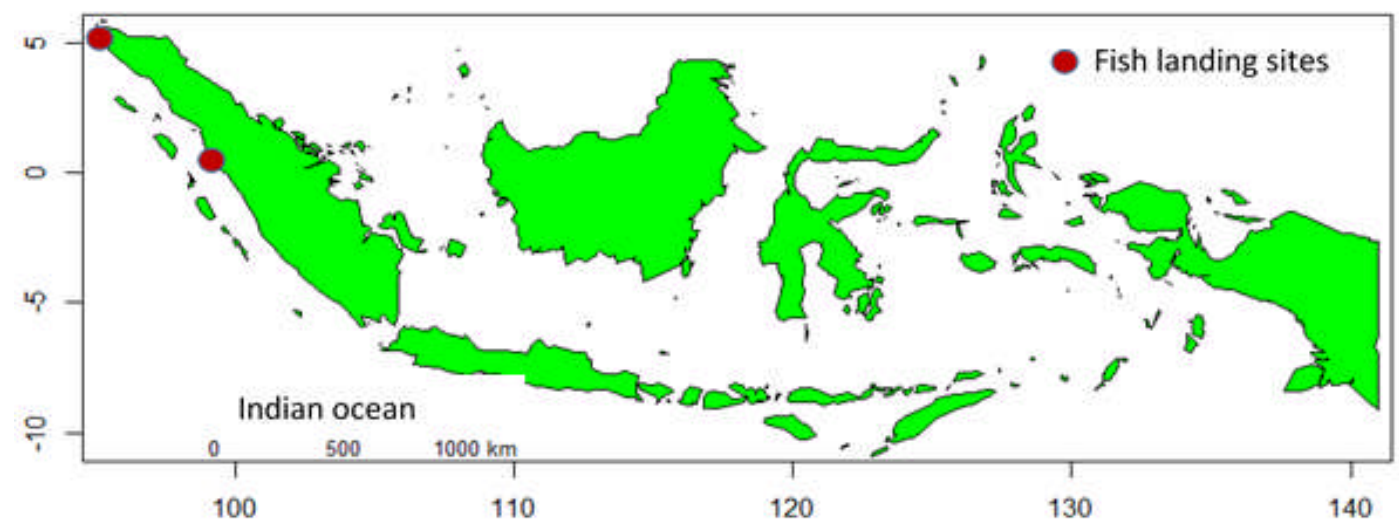

Figure 1. Map showing the study area in the western part of Sumatera

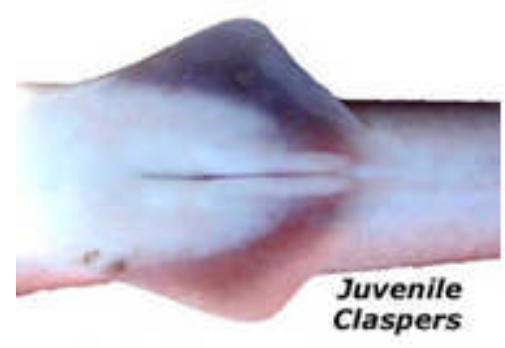

(A)

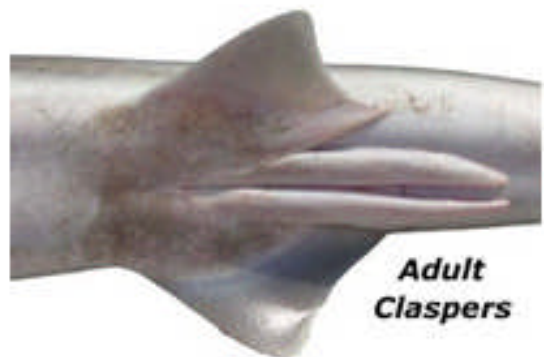

(B)

Figure 2. Clasfer condition with non or partially calcified (A) and fully calcified (B) 
Table 1. Species composition and size of shark caught from western Sumatera waters.

\begin{tabular}{|c|c|c|c|c|c|}
\hline Scientific name & Sommon name & $\begin{array}{l}\text { Number } \\
\text { (ind.) }\end{array}$ & $\%$ by number & $\begin{array}{l}\text { Min.size } \\
(\mathrm{cm})\end{array}$ & $\begin{array}{l}\text { Max.size } \\
(\mathbf{c m})\end{array}$ \\
\hline \multicolumn{6}{|l|}{ Carcharhinidae } \\
\hline Carcharhinus sorrah & Spot-tail shark & 683 & 22.8 & 54 & 152 \\
\hline C. falciformis & Silky shark & 404 & 13.5 & 56 & 234 \\
\hline C. brevipinna & Spinner shark & 44 & 1.5 & - & - \\
\hline C. melanopterus & Blacktip reef shark & 8 & 0.3 & 80 & 157 \\
\hline C. longimanus & Whitetip shark & 6 & 0.2 & 129 & 197 \\
\hline C.leucas & Bull shark & 230 & 7.7 & 102 & 330 \\
\hline C. altimus & Bignose shark & 19 & 0.6 & - & - \\
\hline Galeocerdo cuvier & Tiger shark & 173 & 5.8 & 95 & 350 \\
\hline Triaenodon obesus & Whitetip reef shark & 1 & 0.03 & - & - \\
\hline \multicolumn{5}{|l|}{ Sphyrnidae } & 65 \\
\hline $\begin{array}{l}\text { Sphyrna lewini } \\
\text { Triakidae }\end{array}$ & Scallopade hammerhead & 291 & 9.7 & 39 & 270 \\
\hline $\begin{array}{l}\text { Hemitriakish sp. } \\
\text { Lamnidae }\end{array}$ & Indonesian houndshark & 139 & 4.6 & - & - \\
\hline \multicolumn{5}{|l|}{ Alopiidae } & 210 \\
\hline \multicolumn{5}{|l|}{ Stegostomatidae } & 300 \\
\hline $\begin{array}{l}\text { Stegostoma fasciatum } \\
\text { Hemicyllidae }\end{array}$ & Zebra shark & 52 & 1.7 & 193 & 231 \\
\hline \multicolumn{6}{|l|}{ Squalidae } \\
\hline $\begin{array}{l}\text { Squalus nasutus } \\
\text { Orectolobidae }\end{array}$ & Western longnose spurdog & 250 & 8.3 & 48 & 65 \\
\hline $\begin{array}{l}\text { Orectolobus ornatus } \\
\text { Gynglymostomatidae }\end{array}$ & Indo wobbegong & 6 & 0.2 & 71 & 101 \\
\hline \multirow[t]{2}{*}{ Nebrius ferrugineus } & Tawny nurse shark & 12 & 0.4 & 80 & 305 \\
\hline & Total & 2986 & 100 & & \\
\hline
\end{tabular}

The fist dominant family shark landed was carcharhinidae, which is about $63,1 \%$ for total number of sharks recorded and the second dominant Sphyrnidae which is contribut about $10 \%$ (Fig.3). In this study, several species recorded were estimated in Appendix II of CITES, Hammerhead shark (Sphyrna spp) and Whitetip shark (C.longimanus). However C. longimanus made up less than $1 \%$ of the total catch landed at two main landings sites in western Sumatera.

There were three types of fishing gear operated in western Sumatera, which potentially captured sharks and rays as bycatch. Those were tuna longline, bottom gillnet and handline. 


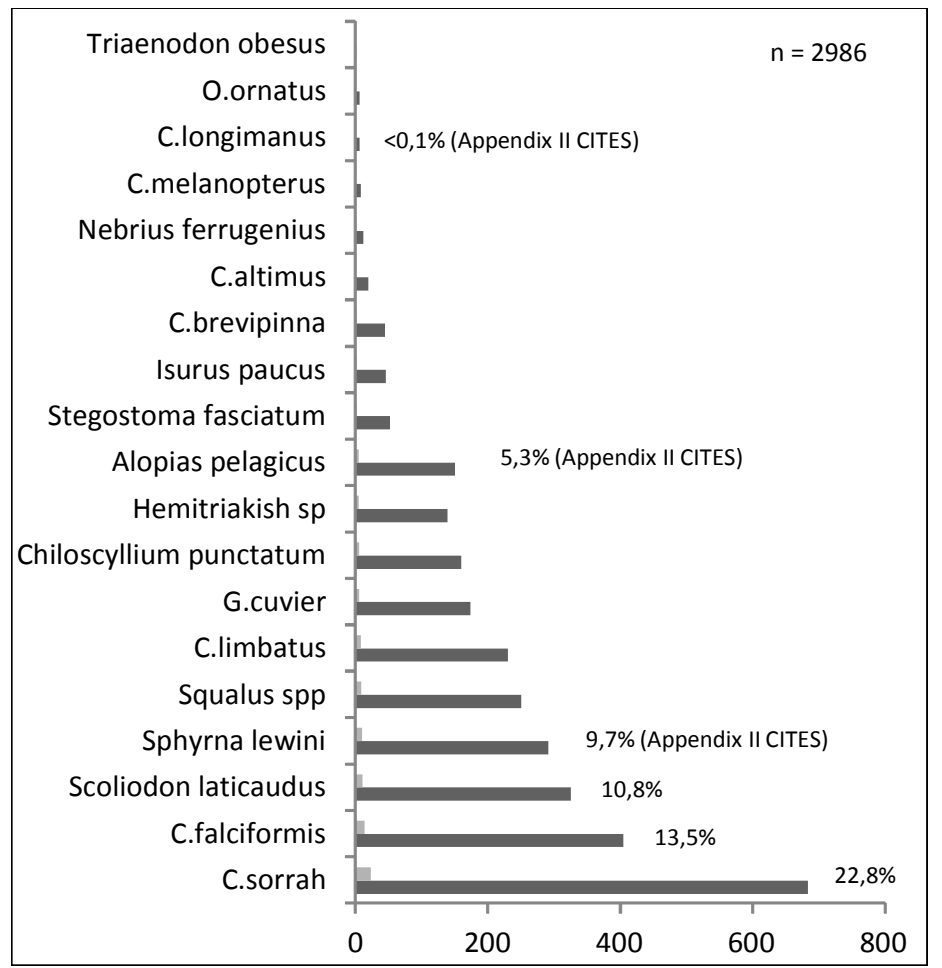

Figure 3. Species composition of shark landed at West Sumatera.

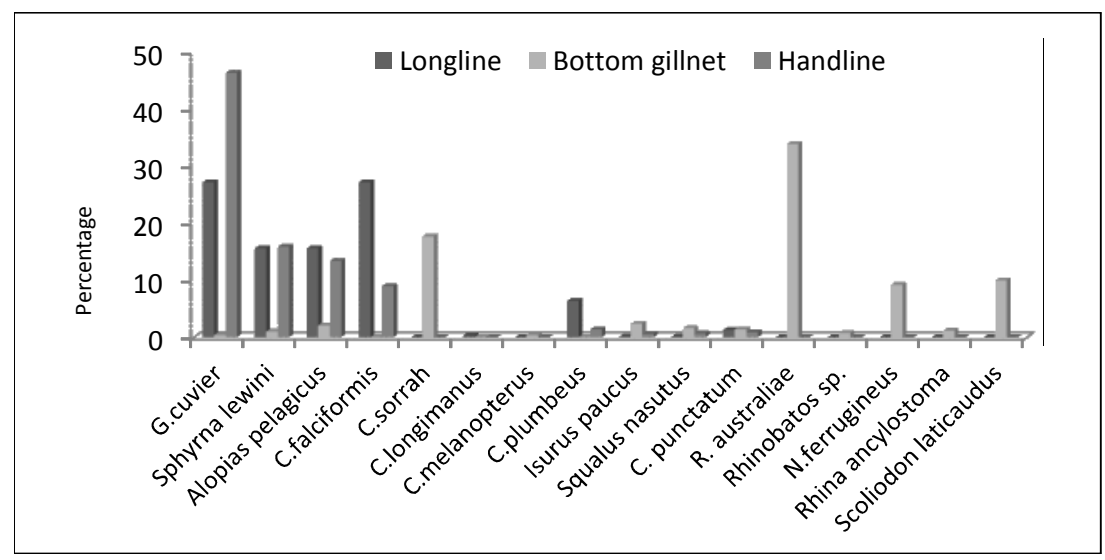

Figure 4. Catch composition of shark and ray based on fishing gear.

The species composition of shark that was caught by tuna longline and handline have similarities domination. They were dominated by tiger shark (Galeocerdo cuvier), Scollape hammerhead (Sphyrna lewini), thresher sharks (Alopias spp) and Silky shark (Carcharhinus falciformis) (Fig.4). The percentage of each species caught by tuna longline were $27.2 \%$, $15.6 \%, 15.6 \%$ and $27.2 \%$, and for the handline were $46.4 \%, 15.9 \%, 13.4 \%$ and $9 \%$, respectively. However, the catches of bottom gillnet were dominated by whitesspotted guitarfish, Rhynchobatus australiae (33.9), Spot-tail shark, Carcharhinus sorrah $(17.7 \%)$, and Tawnynurse shark, Nebrius ferrugineus (9, $2 \%)$ respectively.

\section{Size Composition}

The dominant size composition of sharks landed at the two fish landings sites (Sibolga and Lampulo) is presented in Fig. 5. The size compositions of each species were:

Family Carcharhinidae : Total of 193 C. sorrah was recorded, which 87 were females and 106 males. Females and males length ranged from 57 to $115 \mathrm{~cm}$ and 54 to $119 \mathrm{~cm}$, respectively [Fig. 5(a)]. Based on the figure, there were at least three age groups both of males and females and they have the same size pattern. The males and females in the age group of 
$50-70 \mathrm{~cm}, 71-90 \mathrm{~cm}$ and the total length including the young group, and in the cohort between $91-120 \mathrm{~cm}$ total length is a adult group. White et al. (2006) mentioned that length size of spot- tail shark (C.sorrah) can attains at least $160 \mathrm{~cm}$; males mature at 103$115 \mathrm{~cm}$ and females at $110-118 \mathrm{~cm}$.

Total recorded of Galeocerdo cuvier were 102 which 57 were females that have length ranged $103-$ $350 \mathrm{~cm}$ and 45 were males that have length ranged $145-344 \mathrm{~cm}$ [Fig. 5(b). The males and females in the age group of $145-344 \mathrm{~cm} \mathrm{~cm}$, and $103-350 \mathrm{~cm}$ total length, respectively [(Fig.5(b)]. Total of 87 Silky shark (C.falciformis) were recorded, of which 37 were female and 25 males. The males and females in the age group of $43-44 \mathrm{~cm}$ and $65-165 \mathrm{~cm}$ total length, respectively [(Fig.5(c)].
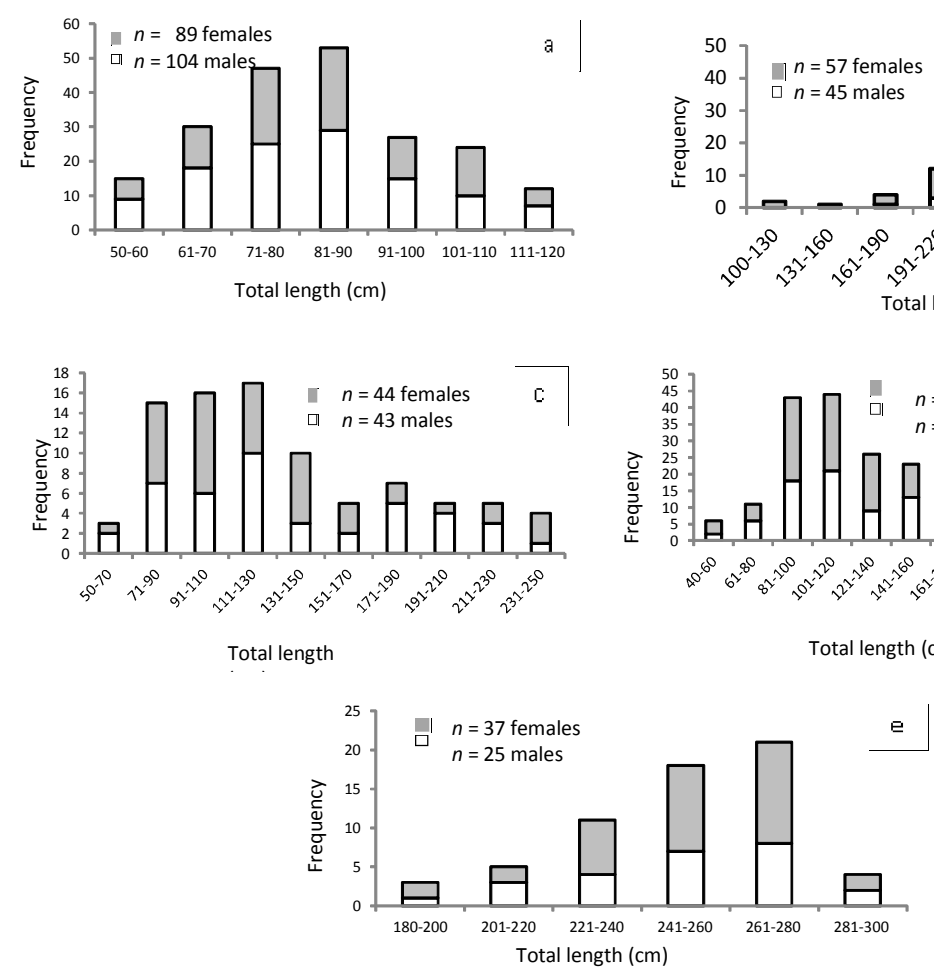

Figure 5. Frequency length of Carcharhinus sorrah (a), Galeocerdo cuvier (b), Carcharhinus falciformis (c), Sphyrna lewini (d), and Alopias pelagicus (e).

\section{Sex Ratio}

One of the success factors of fish reproduction in maintaining the population is by determining sex comparison or sex ratio. In this study, sex ratios of Carcharhinus falciformis, C. sorrah, Galeocerdo

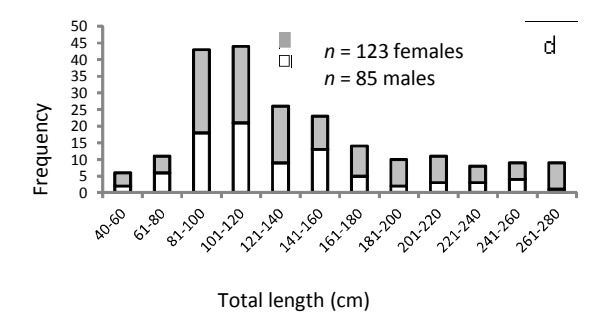

Family Sphyrnidae : Total of 208 Sphyrna lewini was recorded, which 123 were females and 85 males. Females and males measured from 83 to $270 \mathrm{~cm}$ and 38 to $218 \mathrm{~cm}$ total length, respectively [Fig. 5(d)]. The males and females between the age group of 40-140 $\mathrm{cm}$ total length including the young group, and in the age group of $141-280 \mathrm{~cm}$ total length is a adult group.

Family Alopiidae: Total of 62 A. pelagicus were recorded, which 37 were females and 25 were males. Females and males measured from 182 to $295 \mathrm{~cm}$ and 245 to $300 \mathrm{~cm}$ total length, respectively [Fig. 5(e)]. A study of this species from Indian ocean on the length frequency of male Alopias pelagicus showed that the lowest size range of 150-170 $\mathrm{cm}$ total length (immature) and the highest frequency was at range between $251-270 \mathrm{~cm}$ total length with $260 \mathrm{~cm}$ mode (mature, non reproductive).

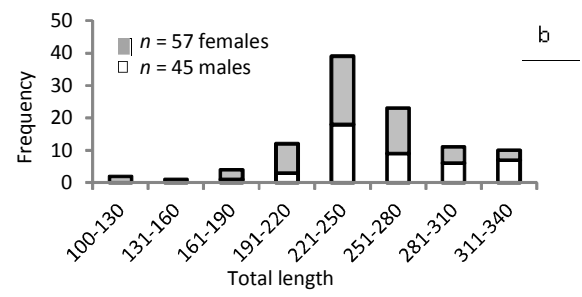

e

cuvier, Alopias pelagicus, and Sphyrna lewini, were $1: 1,7 ; 1,3: 1 ; 1: 1,6 ; 1: 1,9$, and $1: 1,6$, respectively (Fig.6). In general the sex ratios for those shark species landed at Lampulo and Sibolga landings sites in October 2013 to June 2014 were not in balance. 


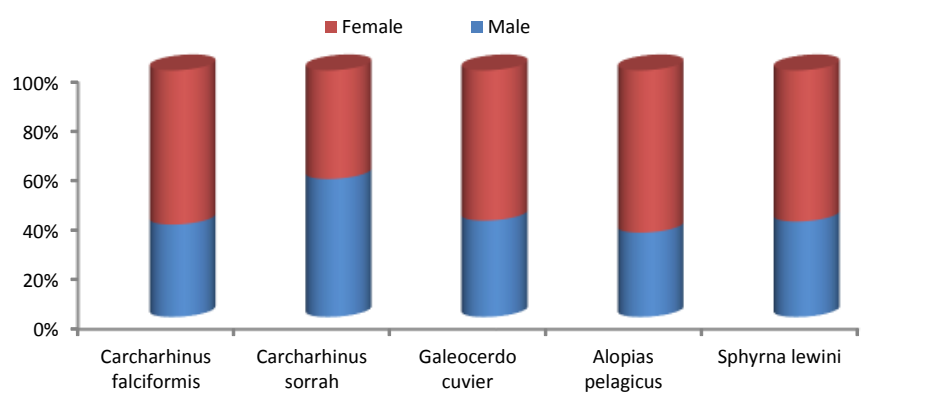

Figure 6. Sex ratio of C. falciformis, C.sorrah, Galeocerdo cuvier, Alopias pelagicus, and Sphyrna lewini.

Carcharhinus sorrah : This species is a commonly caught in west Indian ocean landed at West Sumatera. In this study the length at first maturity $(\mathrm{Lm})$ of Spot-tail shark were found in size $87,1 \mathrm{~cm}$ (Fig. 7a).

Galeocerdo cuvier: In west Sumatera, this species was caught by longline and contribute about less than $10 \%$ from the total landings in 2013-2014. The proportion of maturity and length at $50 \%$ maturity for male of tiger shark shows in Figure 7.

\section{Length at first maturity}

Data available for the length at first maturity of shark during the study we recorded only two species were Spot-tail shark, Carcharhinus sorrah and Tiger shark, Galeocerdo cuvier (Fig. 6). Length at first maturity we found during the study of Carcharhinus sorrah and Galeocerdo cuvier were $87,1 \mathrm{~cm}$ and 213,2 $\mathrm{cm}$, respectively. Biology of those species in Indian Ocean is still not well documented, especially in the western Indian Ocean. Spanswick (2006) mentioned in Australian waters the Carcharhinus sorrah can reach sexual maturity at $90-95 \mathrm{~cm}$ after two or three years can exceed $160 \mathrm{~cm}$ in length but is more frequently $90-100 \mathrm{~cm}$. For the species of Galeocerdo cuvier, males reach sexual maturity at $285-310 \mathrm{~cm}$ total length (TL), while females mature at $287-345 \mathrm{~cm}$ TL (Clark \& van Schmidt 1965, Simpfendorfer 1992, Whitney \& Crow 2007) and the length at first maturity range $210-350 \mathrm{~cm}$.

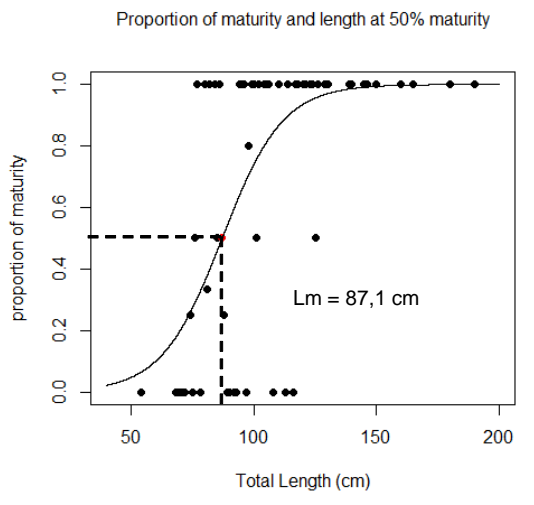

(a)

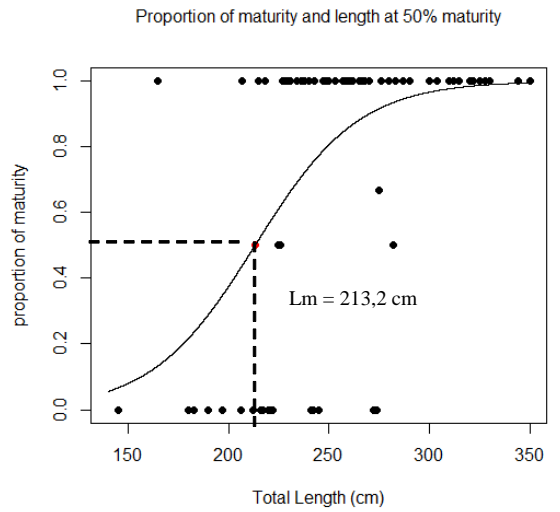

(b)

Figure 7. Length at first maturity of Spot-tail shark, Carcharhinus sorrah(a) and Tiger shark, Galeocerdo cuvier (b)

\section{Shark Fisheries}

The largest contribution of shark catches were from Banda Aceh and Sibolga. Sharks landed at Banda Aceh are from targeted shark longlines and bycatch from tuna longlines and tuna handlines. Sharks landed at Sibolga are bycatch from bottom gillnets and purse seines. The sharks landed at Lampulo-Banda Aceh fish landings sites are from surface longlines and hand lines operated from small boats $5 \mathrm{GT}$. Shark surface longlines are used by fishing vessels with specifications of $11 \mathrm{~m}$ length, 2,6-m width, 0,8 $\mathrm{m}$ depth and having a pair of 30 horse power (HP) machines. This fishing gear has a main line with $8 \mathrm{~mm}$ diameter $\mathrm{PE}$ (polyethelene) rope, and $2 \mathrm{~m}$ branch lines with $4 \mathrm{~mm}$ diameter PA (polyamide) rope. Commonly J hook type number $1 / 0$ or $2 / 0$ used for shark longline. Each branch has a hook at the end of the rope. The main line length is $500 \mathrm{~m}$ and consists of 70 hooks with 4 $\mathrm{m}$ distance between the hooks. It takes a few hours 
for getting to fishing area from the landings site. They begin to set hooks at 15.00 to 18.00 p.m. and hauled at 04.00 to 07.00 a.m., depending on the catch. The fishermen usually use baits with small pelagic fishes (mackerel, sardines, squids). In order to catch baits, a hand line is usually set in the morning and hauled in the afternoon. The surface longlines operated by 45 crews in Lampulo spends 7-15 days at sea. There is no specific target species, but sharks are dominate catches. Shark species from the family of Carcharhinidae such as Spot-tail shark (Carcharhinus sorrah), Silky sharks (Carcharhinus falciformis), and Spadenose shark (Scoliodon laticaudus) are often caught by this gear.

Fishing areas for shark surface longlines and shark handlines are presented in Fig.8. It seems there are similar fishing areas for those fishing gears.

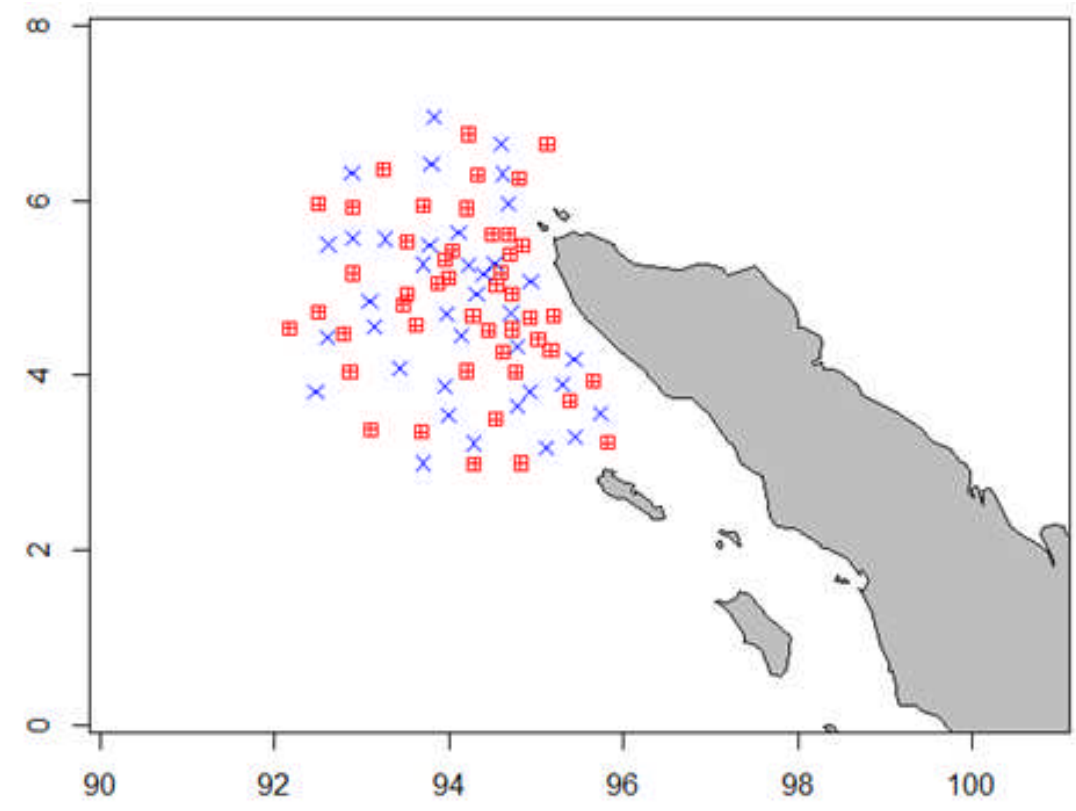

Figure 8. Map of the fishing area for shark surface longline (red) and handline (blue) in Lampulo, Banda Aceh.

\section{Discussion}

The shark fisheries in western Sumatera contributed about $12.3 \%$ of the national shark production (DGCF, 2013). There are 20 species of 10 families of sharks caught in the western Indian Ocean landed at west Sumatera (Lampulo, Banda Aceh and Sibolga North Sumatera). The domimated caught of sharks is C. sorrah (23\%), C.falciformis (13,5\%), Scoliodon laticaudus $(10,8 \%)$, and Sphyrna lewini $(9,7 \%)$. In this study, several species recorded listed in Appendix II of CITES are Hammerhead shark (Sphyrna spp) and Whitetip shark (C.longimanus). Species S. lewini ranged about $39-270 \mathrm{~cm}$, but almost for this species were small size (juvenile-immature). The maximum size of Sphyrna lewini is $367 \mathrm{~cm}$ (Dudley \& Simpfendorfer 2006). Hazin et al. (2001) described that the size of majority maturing female sampel was range about 213.5 to $255 \mathrm{~cm}$ TL found in the Northeastern Brazil waters. However, C. longimanus contributed less than $1 \%$ of the total catch landed at two main landings sites. Other study reported that species of S.lewini commonly caught in
Java Sea by gillnet were juvenile-immature condition (Yuneni, 2014). Commonly, in Indonesia waters, S.lewini juvenile was founded in coastal waters, which are typically the fishing grounds for intensive utilization fisheries (Fahmi \& Dharmadi 2013). Stricter policies are needed to regulate how to exploitation resources friendly, especially juvenile shark. In addition, fishing gear was used by fishers are not very selective, that make many juvenile sharks were caught as bycatch (Dharmadi et al., 2015).

Coastal waters are subjected to high fishing pressure from artisanal fishers using a variety of non selective gear types that take a high proportion of juveniles. In this area are spawning and nursery grounds for numerous of fish and shark (Heupel et al., 2007; Nagelkerken et al., 2008).

The percentage of each species caught by tuna longline were $27.2 \%, 15.6 \%, 15.6 \%$ and $27.2 \%$, while for the handline it was $46.4 \%, 15.9 \%, 13.4 \%$ and $9 \%$, respectively. However the catches of bottom gillnet were dominated by whitesspotted guitarfish, 
Rhynchobatus australiae (33.9), Spot-tail shark, Carcharhinus sorrah (17.7\%), and Tawnynurse shark, Nebrius ferrugineus $(9,2 \%)$ respectively. Size composition of the females and males length ranged of C. sorrah from 57 to $115 \mathrm{~cm}$ and 54 to $119 \mathrm{~cm}$, respectively [Fig. 6(a)]. Carcharhinus sorrah is a coastal pelagic shark of the tropical and sub-tropical Indo-West Pacific reaching $1.6 \mathrm{~m}$, and a common catch component of line, net and trawl fisheries over tropical continental shelves from intertidal zone to a depth of at least $80 \mathrm{~m}$ (Last \& Stevens, 2009), and it is found mainly in mid water or near the surface. Sexual maturity about $90-95 \mathrm{~cm}$ after two or three years, it can be upto exceed $160 \mathrm{~cm}$ but is more frequently $90-100 \mathrm{~cm}$ (Spanwick, 2006).

Based on the Figure 4, there are group at 3 age of both males and females that have the same size pattern. The males and females in the age group of $50-70 \mathrm{~cm}, 71-90 \mathrm{~cm}$ and the total length including the young group, and in the cohort between $91-120 \mathrm{~cm}$ total length is a adult group. According to Compagno (1984) this species can attains at least $160 \mathrm{~cm}$; males mature at $103-115 \mathrm{~cm}$ and females at $110-118 \mathrm{~cm}$. There were as substantial landings of $C$.falciformis and S. laticaudus (Fig.4), which are also common in the tropical Indo-West Pacific. Dharmadi et al. (2013) reported that majority of $C$. falciformis caught in eastern Indian Ocean are immature $(75,9 \%)$ and only $24.1 \%$ are mature. The length frequency of the Silky sharks fluctuates between $50-250 \mathrm{~cm}$, dominated by $100 \mathrm{~cm}$ individuals corresponding to immature individuals (Oshitani et al., 2003). The estimated mean $L T$ as birth of females $(811 \mathrm{~mm}$, range: $79,9-82,3 \mathrm{~cm})$ and males $(81,2 \mathrm{~cm}$, range: $79,4-83,0$ $\mathrm{cm}$ ), derived from the back calculations correspond to the birth zones in the centra, were not significantly different $(P>0.05)$. The $L T$ ranges in the catches of post-natal females $(57,0-259,2 \mathrm{~cm})$ and males $(55,3-$ $228,9 \mathrm{~cm})$ taken by gillnetting were wider of the females (117,7-262,3 cm) and males (118,4-240,9 $\mathrm{cm}$ ) were taken by longlining (Hall et al., 2012). The catches of other species, such as Prionace glauca, were represented almost entirely by mature fish, indicating that the fishing gear does not capture their juveniles or that the juveniles of these species occur in habitats where fishing pressure was limited. $P$. glauca juvenile are known to occur in separate areas from the adults in other regions (Stevens, in White, 2003).

The lowest frequency of female Alopias pelagicus was at size of $291-310 \mathrm{~cm}$ total length (mature), and the highest length frequency of female $A$. pelagicus was between 231-250 cm (Dharmadi et al., 2013). The length frequency both of sexes of $A$. pelagicus shows that females generally are larger than males. Liu et. al. in Camhi et al. (2008) mentioned that the growth of females of the Alopiidae is faster than males. A. pelagicus from the Indian Ocean can reach the maximum length up to $365 \mathrm{~cm}$. Males reach adult at size about $240-250 \mathrm{~cm}$ and females at $260-285 \mathrm{~cm}$ (White et al., 2006; White, 2007). Liu et al. (1999) reported that the total length at maturity was $282-292$ $\mathrm{cm}$ for females and 267- $276 \mathrm{~cm}$ for males. Based on the results of this study, it can be concluded that the majority A.-pelagicus caught from the Indian Ocean on 2002-2007 are commonly as adult stage (mature non reproductive or mature sexually).

In this study, the length at first maturity of Galeocerdo cuvier was $\mathrm{Lm}=213,3 \mathrm{~cm}$ (Fig. $6 \mathrm{~b}$ ). Last \& Steven (2009) mentioned this species born at 50$80 \mathrm{~cm}$ and attains approximately $600 \mathrm{~cm}$. While White et al. (2006) reported that this species can be up to $740 \mathrm{~cm}$, males mature about $300-305 \mathrm{~cm}$ and females about $250-350 \mathrm{~cm}$. Males mature at about $300 \mathrm{~cm}$ and females at about $330 \mathrm{~cm}$. The tiger shark commonly reaches a length about $325-425 \mathrm{~cm}$ and weight over $385-635 \mathrm{~kg}$. Length at birth varies from $51-76 \mathrm{~cm}$. Males reach sexual maturity about 226$290 \mathrm{~cm}$, while females become mature about 250$325 \mathrm{~cm}$.

\section{CONCLUSION}

The sharks are targeting from shark longlines and bycatch from tuna longlines and tuna handlines in Lampulo, Banda Aceh. Whilst in Sibolga, sharks are caught as bycatch from fish net, bottom gillnet and purse seine. The shark fishing activities by using longlines and handlines were done in the same fishing area in the west of Sumatera waters. There were at least 20 species of shark caught in Indian Ocean and landed at those fish landings sites, dominated by Spot tail shark (23\%) and Silky shark (13\%), whereas Hammerhead shark contributed about $10 \%$ and Oceanic whitetip shark was only less than $1 \%$. Part of Spot tail shark, Silky shark, and Scalloped hammerhead caught in those area are immature, while for part of Tiger shark and Pelagic thresher are matured. The sex ratios for Spot tail shark, Silky shark, Tiger shark, Pelagic thresher, and Scalloped hammerhead caught and landed at Lampulo and Sibolga fish landings sites were not balance.

\section{ACKNOWLEDGEMENTS}

Special thanks go to Munawir and Musda Sibarani as an enumerators at Lampulo-Banda Aceh and Sibolga-North Sumatera for they assistance in the field throughout the project. Thanks also to Prof. Dr. 
Hari Eko Irianto, Director of Research Center for Fisheries Management and Conservation for help in this project. This research was funded by Bay of Bengal Large Marine Ecosystem (BOBLME) Project (GCP/RAS/236/GFF) in 2013-2014 under the project : "Data Quality Improvement and Awareness Building of Shark".

\section{REFERENCES}

Bonfil, R. (2002). Trends and patterns in world and Asian elasmobranch fisheries. In: Fowler SL, Reed TM, Dipper FA (eds), Elasmobranch biodiversity, conservation, and management: Proceedings of the International Seminar and Workshop, Sabah, Malaysia, July 1997. Gland, Switzerland, and Cambridge, UK: IUCN SSC Shark Specialist Group. p. 15-24.

Camhi, M.D., Ellen K.P., \& Elizabeth, A.B. (2008). Sharks of the Open Ocean. Bilogy, Fisheries and Conservation. Fish and Aquatic Resources Series 13. Blackwell Publishing. USA. p. 60-65.

Clark, E., Von Schmidt, K. (1965). Sharks of the central Gulf coast of Florida. Marine Science Bulletin, 15, 13-83.

Compagno, L.J. (1984). FAO species catalogue. Vol. 4. Sharks of the world. An annotated 764 and illustrated catalogue of sharks species known to date. Part 2. 765. Carcharhiniformes.

DGCF. (2013). Indonesia Capture Fisheries Statistics. Ministry of Marine and Fisheries Affairs. Directorate General of Capture Fisheries). Vol 13, No.1. ISSN : 1858-0505. 240p.

DGCF. (2014). Indonesia Capture Fisheries Statistics. Ministry of Marine and Fisheries Affairs. Directorate General of Capture Fisheries). 12.(2), 484.

DGCF. (2015). Indonesia Capture Fisheries Statistics. Ministry of Marine and Fisheries Affairs. Directorate General of Capture Fisheries). p. 427.

Dudley, S.F.J., \& Simpfendorfer, C.A. (2006). Population status of 14 shark species caught in the protective gillnets off KwaZulu-Natal beaches, South Africa, 1978-2003. Marine and Freshwater Research 57, 225-240.
Dharmadi, Faizah, R., \& Sadiyah, L. (2013). Shark longline fishery in Tanjung Luar-East Lombok. Indonesia Fisheries Research Journal. AMFRMMAF. 19(1), 39-46.

Dharmadi, Fahmi \& Satria, F. (2015). Fisheries management and conservation of sharks in Indonesia. African Journal of Marine Science. 37 (2), 249-258.

Fahmi \& Dharmadi. (2013). A review of the status of shark fisheries and shark conservation in Indonesia (p. 187 ) [in Bahasa]. Jakarta: Direktorat Konservasi Kawasan dan Jenis Ikan, Kementerian Kelautan dan Perikanan.

Hall, N.G., Bartron, C., White, W. T., Dharmadi \& Potter, I. C. (2012). Biology of the Silky shark Carcharhinus falciformis (Carcharhinidae) in the eastern Indian Ocean, including an approach to estimating age when timing of parturition is not well defined. Journal of Fish Biology (2012) 80, 1320-1341. doi:10.1111/j.1095-8649.2012. 03240.x, available online at wileyonlinelibrary.com.

Fabio Hazin, Alessandra Fischer \& Matt Broadhurst. (2001). Aspects of reproductive biology of the Scalloped hammerhead shark, Sphyrna lewini, off northeastern Brazil. Environmental Biology of Fishes. Kluwer Academic Publishers. 61, 151159. Printed in the Netherlands.

Heupel, M.R., Carlson, J.K., \& Simpfendorfer, C.A. (2007). Shark nursery areas: concepts, definition, characterization and assumptions. Marine Ecology Progress Series. 337, 287-297.

King, M.G. (2007). Fisheries Biology, Assessment, and Management 2nd Edition (p. 379 ). Blackwell Publishing. Australia.

Lack, M., \& Sant, G. (2006). Confronting shark conservation head on! (p. 29)Cambridge: TRAFFIC International.

Lack, M., \& Sant, G. (2009). Trends in global shark catch and recent developments in management (p. 29 ). Cambridge: TRAFFIC International.

Last, P.R., \& Stevens, J.D. (2009). Sharks and Rays of Australia (p. 644 ). CSIRO Publishing Australia. 
Liu, K.M., Ch-T Chen, Liao, T.H ., \& Sh-J Joung. (1999). Age, growth, and reproduction of the pelagic thresher shark, Alopias pelagicus in the Northwestern Pacific. Copeia: 1999, Issue: volume 1, Pages: 68-74.

Nagelkerken, I., Blaber S.J.M., Bouillon, S., Green, P., Haywood, M., \& Kirton, L.G. (2008). The habitat function of mangroves for terrestrial and marine fauna: a review. Aquatic Botany $89,155-185$.

Oshitani, S., Nakano, H., \& Tanaka, S. (2003). Age and growth of the Silky shark Carcharhinus falciformis from the Pacific Ocean. Fisheries Science 69, 456-464.

Simpfendorfer, C. (1992). Biology of the tiger sharks (Galeocerdo cuvier) caught by the Queensland shark meshing program off Townsville, Australia. Marine and Freshwater Research, 43, 33-43.

Spanwick, N. (2006). Black-tip sharks. Biology and Fishery of two commercially important species. Fishnote. No.30. Departement of Primery Industry, Fisheries and Mines, Nothern Teritorry Goverment. 2006. ISSN 1035-008x. p.4.
White, W.T. (2003). Aspects of the biology of elasmobranchs in a subtropical embayment in Western Australia and of chondrichthyan fisheries in Indonesia. Thesis. Murdoch University, Western Australia. 207 p. (unpublished).

White, W.T., Last, P.R., Stevens, J.D., Yearsley, G.K., Fahmi \& Dharmadi. (2006). Economically Important Sharks and Rays of Indonesia. National Library of Australia Cataloging-in-Publication entry . Australia. 329 p.

White, W.T. (2007). Biological observations on lamnoid sharks (Lamniformes) caught by fisheries in eastern Indonesia. Journal of the Marine Biological Association of the United Kingdom, 87, 781-788.

Whitney, N.M., \& Crow, G. L. (2007). Reproductive biology of the tiger shark (Galeocerdo cuvier) in Hawaii. Marine Biology, 151, 63-70.

Yuneni, R.R. (2014). Laporan hasil awal program enumerasi hiu di Pelabuhan Indramayu, Tegal, Muncar, dan Lamongan. Shark Bycatch Program - WWF Indonesia. p. 9.

Zainudin, I.M. (2011). Fisheries management of shark based on ecosystem in Indonesia. (Thesis). University of Indonesia, Depok. 93 pp (in bahasa). 